\title{
Accounts and Bookkeeping
} in the Ancient World

Edited by

Andrea Jördens and Uri Yiftach

\section{PHILIPPIKA}

Altertumswissenschaftliche Abhandlungen Contributions to the Study of Ancient World Cultures 55,2

Harrassowitz Verlag 


\section{Contents}

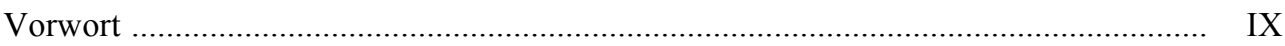

Ten Years LDAS: Summary of Activities and Results ......................................... XI

Contributors

\section{ANCIENT NEAR EAST}

Manuel Molina

Who watches the watchers?

New evidence on the role of foremen in the Ur III administration

Daniel E. FLEMING

Writing as Administrative Option:

The Diviner of the Gods at Late Bronze Age Emar

Melanie GROß

"The total of the crown prince's revenues" -

Record-keeping in the Neo-Assyrian palaces

ANCIENT GREECE

Julia LOUGOVAYA

Tamiai in Early Greece

Véronique CHANKOWSKI

Greek Sanctuaries as Administrative Laboratories:

Bookkeeping Experience on Delos, from Wood Tablets to Marble Steles

Cristina CARUSI

The Evolving Format of Building Accounts in Classical Athens

David LEWIS

Misthos, Apophora, or Something Else?

A Fresh Look at SEG XXXV 134 


\section{GRAECO-ROMAN EGYPT}

Willy CLARYSSE

Headers for lists and accounts in ancient documents and in modern editions

Katelijn VANDORPE and Nick VANEERDEWEGH

Surveying the land in Ptolemaic Egypt.

The information flow from village to nome level

Sandra L. LIPPERT and Maren SCHENTULEIT

Agreements and accounts.

On-going research on economic activities of the temple

of Soknopaiou Nesos according to the Demotic Texts

Andrea JÖRDENS

Buchführung und Rechnungswesen in der Gutsverwaltung

Patrick SÄNGER

Registrierung und Beurkundung von vó $\mu$ or im Grapheion von Tebtynis

Nicola REGGIANI

Identifying People in Official Reports:

The Administrative Practice in Roman Egypt

Thomas KRUSE

Fiskalische Buchführung in Theadelpheia

Uri YIFTACH

Kollêma: Cross Referencing in Roman Egypt

\section{ROME AND THE EMPIRE}

Ornella SALATI

Format and Features of Military Account-Books:

the Case of PSI II 119 recto + ChLA IV 264

Éva JAKAB

Öffentliche Abrechnungen: Cicero in Kilikien 
Miklós KÖNCZÖL

Accounting and Bookkeeping: The Literary Sources

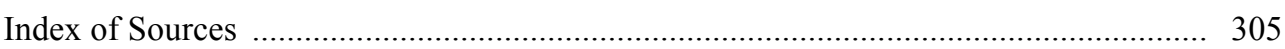

Cuneiform Sources ......................................................................................... 305

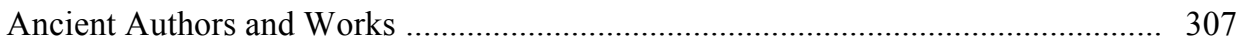

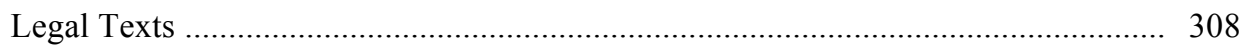

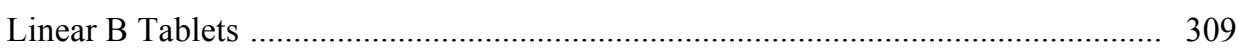

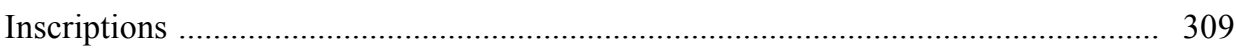

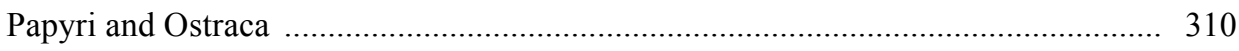

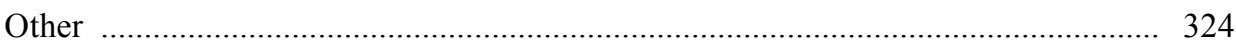




\section{Vorwort}

„Running a state is based on absorbing, processing and safekeeping information on its population and territory. The said operations are conducted by a series of officials and a range of bureaus whose cooperation is indispensable for the effective performance of these tasks. One mode of cooperation is vertical. A lower instance collects information on site and then forwards it to a higher instance, where the information is used to verify that past decisions were put into practice and as a basis for taking future ones. Still, bureaucratic apparatuses are pyramid-shaped, meaning that the higher instance is expected to receive information from more than one subordinated instance. Consequently, were the higher instance to receive the mass of raw information as collected by each and every subordinated instance on site, it would simply not possess the intellectual capacity of internalizing or deploying the data for its purposes. Accordingly, one of the key tasks facing the lower instances would be to convert the data of its operations in a new, handy format that could be feasibly processed and applied by its superiors."

Mit diesen wenigen Sätzen ist die Problemstellung umrissen, die am Ausgang unser gemeinsamen Forschungen zum Thema Synopsis: Data Processing and State Management in Roman Egypt (150 BCE-300 CE) stand. Den Abschluß des mehrjährigen Gemeinschaftsprojektes, das von 2013 bis 2016 von der German-Israeli Foundation gefördert wurde, ${ }^{2}$ bildete eine vom 22. bis 24. September 2016 in Schwetzingen nahe Heidelberg veranstaltete Tagung, deren Akten nunmehr hiermit publiziert werden. Unter dem Titel Accounts and Bookkeeping in the Ancient World: Question of Structure wurde sie zugleich als achtes Treffen der von Uri Yiftach mitbegründeten Arbeitsgruppe Legal Documents in Ancient Societies durchgeführt.

Diese Entscheidung erwies sich als überaus glücklich, erlaubte dies doch, die von uns erarbeiteten Ergebnisse, die vornehmlich an den aus dem griechisch-römischen Ägypten überlieferten Papyri gewonnen wurden, mit verwandtem Quellenmaterial anderer antiker Kulturen abzugleichen. Während dreier intensiver Tage wurde nicht nur immer wieder vor Augen geführt, welch großes Potential das stets unterschätzte und nur scheinbar unattraktive Format der Listen und Verzeichnisse besitzt, sondern auch, welch hoher Erkenntnisgewinn gerade aus einer solchen vergleichenden Betrachtung erwachsen kann. Die jetzt in gedruckter Form vorgelegten Beiträge haben die in sie gesetzten Erwartungen jedenfalls auf das schönste bestätigt. Der daraus zusammengestellte Band sieht sein Ziel erfüllt, wenn es ihm gelingt, zu weiterer Diskussion dieser oft zu unrecht vernachlässigten Textgattung anzuregen und im Idealfall das auf den ersten Blick recht sperrig wirkende Thema Accounts and Bookkeeping womöglich sogar auf längere Sicht vom Ruch gepflegter Langeweile zu befreien.

1 So die Einleitung unseres gemeinsam bei der German-Israeli Foundation gestellten Antrags; vgl. die folgende Anm.

2 GIF Grant No: G-38-111.4/2011, Laufzeit 01/2013-12/2016; Principal Investigators: Prof. Dr. Andrea Jördens (Universität Heidelberg), Prof. Uri Yiftach-Firanko (Hebrew University, Jerusalem, ab 10/2014 Tel Aviv University); Mitarbeiter: Dr. Shimon Epstein (Jerusalem), Nikolaos Theodorakopoulos und besonders Dr. Nicola Reggiani (beide Heidelberg). 
Den Teilnehmern an der ertragreichen Tagung gilt für ihre Beiträge und ihre Diskussionsbereitschaft nochmals unser herzlichster Dank, ebenso Susanne Rein und vor allem Nicola Reggiani für die unermüdliche Hilfe in der Organisation. Dank schulden wir überdies der German-Israeli Foundation, und zwar sowohl für die großzügige Finanzierung der Tagung wie auch des Projektes als ganzen. Durch den freundlicherweise gewährten Druckkostenzuschuß wurde zudem die Publikation der Akten in derselben Reihe ermöglicht, in der auch schon der erste Band der Reihe Legal Documents in Ancient Societies erschienen war. Sehr zu danken haben wir schließlich erneut vor allem Elke Fuchs, die sich durch ihr nun schon bewährtes Engagement in Sachen Satz und Layout ein weiteres Mal allergrößte Verdienste erworben hat.

Heidelberg, im November 2019

Andrea Jördens - Uri Yiftach 


\section{Ten Years LDAS: Summary of Activities and Results}

The research group Legal Documents in Ancient Societies was founded in 2007 on the initiative of Roger S. Bagnall, then the head of the newly founded Institute for the Study of the Ancient World at New York University. The main objective of the group was to overcome academic compartmentalization in bringing together, and facilitating scientific exchange between students of everyday, legal and administrative documentation in different ancient civilizations and societies. To enable this, a six-headed steering committee was formed, each member representing one field of research. Sophie Démare Lafont (Paris): The Ancient Near East; Mark Depauw (Leuven), later substituted by Katelijn Vandorpe (Leuven): Ancient Egypt; Michele Faraguna (then Trieste): The Greek World; Éva Jakab (Szeged): Rome and Roman Law; Dennis Kehoe (Tulane): Law and Economics; Uri Yiftach (then Jerusalem): Greco-Roman Egypt.

Thanks to the generous support of the Institute for the Study of the Ancient World at New York University, lasting through the group's fourth meeting, and the friendly collaboration of the members of the steering committee it was possible to hold, in the period 20072016 eight meetings, each dedicated to a specific subject. In seeking overarching themes, whose discussion could open new horizons for the study of ancient documentation from hitherto unsought perspectives, Legal Documents in Ancient Societies has discussed in its meetings (each followed by a publication), media of documentation ("The Letter", Rome 2008), the selection, collection and organization of recorded data ("Identifiers", Leuven 2010), preservation and authentication methods of legal and administrative documents ("Archives", Trieste 2011; "Accounts", Schwetzingen 2016), the economic context of, and stimulus for the documentation of legal acts ("Transaction Costs", Washington, DC 2009). Other meetings were dedicated to more 'traditional' themes: Sale (Budapest, 2012), Guardianship (Jerusalem, 2013), and Loan (Paris, 2015). Even here, however, the analysis in the unique framework of cross departmental and doctrinal exchange has yielded new recognitions, which will certainly elicit discussion in years to come.

In the eighth meeting, taking place in Schwetzingen 22.-24.9.2016, was also for me the concluding meeting of ten years of highly intensive and productive collaboration. Taking place under, and funded by the German Israel Foundation for Scientific Research and Development in connection with the project Synopsis: Data Processing and State Management in Roman Egypt (30 BCE-300 CE) (G-38-111.4/2011), we aimed at applying the methodology and discourse slowly developed in the course of the preceding seven meetings, for the study of a genre frequently neglected by students of ancient diplomatics: reports and accounts. As such, it was a worthy conclusion, embodying the innovative and inquisitive spirit that guided Legal Documents in Ancient Societies since its foundation. Particular thanks are due to Andrea Jördens, who generously hosted the meeting in Schwetzingen, and is coeditor of the present volume, and Michele Faraguna, who as chief editor of Edizioni Università di Trieste made the publication of three of the seven volumes listed below possible, and the editors of the series PHILIPPIKA - then Marburger altertumskundliche Abhandlungen, now Altertumswissenschaftliche Abhandlungen / Contribu- 
tions to the Study of Ancient World Cultures - who have thus assumed the publication of both the first, and so-far concluding publication of Legal Documents in Ancient Societies.

Tel Aviv, July 2019

Uri Yiftach

U. Yiftach-Firanko (ed.), The Letter: Law, State, Society and the Epistolary Format in the Ancient World (Legal Documents in Ancient Societies I: Rome, 28-30.9.2008) (PHILIPPIKA: Marburger altertumskundliche Abhandlungen 55,1) (Harrassowitz Verlag, Wiesbaden 2013). ISBN: 978-34-4706-764-5.

D.P. Kehoe, D. Ratzan, U. Yiftach, Law and Transaction Costs in the Ancient Economy (Legal Documents in Ancient Societies II: Washington, D.C., 27-28.7.2009) (University of Michigan Press, Ann Arbor 2015). ISBN: 978-0-472-11960-8.

M. Depauw, S. Coussement (eds.), Identifiers and Identification Methods in the Ancient World (Legal Documents in Ancient Societies III: Leuven and Brussels, 23-25.9.2010) (Peeters, Leuven 2014). ISBN : 978-90-4292-983-8.

M. Faraguna (ed.), Archives and Archival Documents in Ancient Societies (Legal Documents in Ancient Societies IV: Trieste, 30.9-1.10.2011) (EUT Edizioni Università di Trieste, Trieste 2013). ISBN: 978-88-8303-813-6, eISBN: 978-88-8303-814-3.

É. Jakab (ed.), Sale and Community Documents from the Ancient World. Individuals' Autonomy and State Interference in the Ancient World (Legal Documents in Ancient Societies V: Budapest, 5-8.10.2012) (EUT Edizioni Università di Trieste, Trieste 2015). ISBN: 978-88-8303-685-9.

U. Yiftach, M. Faraguna (eds.), Ancient Guardianship: Legal Incapacities in the Ancient World (Legal Documents in Ancient Societies VI: Jerusalem, 3-5.11.2013) (EUT Edizioni Università di Trieste, Trieste 2017). ISBN: 978-88-8303-813-6, eISBN: 978-88-8303-8143 .

S. Démare-Lafont (ed.), Debt in Ancient Mediterranean Societies. A Documentary Approach (Legal Documents in Ancient Societies VII: Paris, 27-29.8.2015) (Hautes Études orientales 56, Moyen et Proche-Orient 8) (Droz, Geneva 2019). ISBN : 978-2-600-05741-7. ISBN PDF : 978-2-600-15741-4.

A. Jördens, U. Yiftach (eds.), Accounts and Bookkeeping in the Ancient World: Question of Structure (Legal Documents in Ancient Societies VIII: Schwetzingen, 24-26.9.2016) (Philippika: Altertumswissenschaftliche Abhandlungen / Contributions to the Study of Ancient World Culture 55,2) (Harrassowitz Verlag, Wiesbaden 2020). ISBN: 978-3-44711198-0. 


\section{Contributors}

Cristina Carusi is Associate Professor of Greek History at the University of Parma. Previously, she held research and teaching appointments at the Center for Hellenic Studies (Washington, DC), the University of Texas at Austin, and the Institute for Advanced Study (Princeton). Her research interests center on Greek history and epigraphy, with special attention to the institutions, law, and economy of Greek city-states. In addition to several articles in international volumes and journals, she authored a book on the production, commerce and taxation of salt in the Greek world and co-edited a volume on the Athenian grain-tax law of $374 / 3$.

Véronique Chankowski is Director of the French School of Athens and Professor of Ancient Economy and Aegean History in the University Lyon 2. As an epigraphist working also with archaeological sources, she has published several studies on ancient Greek economy. She worked on Delos where she studied the rich epigraphic corpus of the sanctuary's accounts, from a financial and monetary history perspective. She also addressed the issue of commercial relations through the study of warehouses and distribution channels in the Mediterranean. Her last book is Parasites du dieu. Comptables, financiers et commerçants dans la Délos hellénistique, Athens, 2019.

Willy Clarysse taught Greek, Coptic and Ancient History including papyrology at the KULeuven. He is a member of the Royal Flemish Academy of Belgium. He published Greek and demotic papyri and ostraca and numerous studies on prosopography, onomastics, institutions, religions and languages of Greco-Roman Egypt. His main projects concern the bilingual documentation of Egypt between Alexander the Great and Mohammed, with books on Fayum villages, papyrus archives and tax lists. He is a collaborator at the database Trismegistos, where he is responsible for the Leuven Database of Ancient Books (LDAB).

Daniel E. Fleming is the Edelman Professor of Hebrew and Judaic Studies at New York University. His range of study spans pre-Classical Mesopotamia, Syria, and Israel through the second and early first millennia BCE. After two early books on the Late Bronze Age Syrian city of Emar (The Installation of Baal's High Priestess at Emar, 1992; Time at Emar, 2000), he has returned to work on the site in collaboration with Sophie DémareLafont (especially "Emar Chronology and Scribal Streams: Cosmopolitanism and Legal Diversity," Revue d'Assyriologie 109 [2015] 45-77). 
Melanie Groß acquired her PhD in Assyriology in 2014 at the University of Vienna and is currently working as a researcher in the project "Persia \& Babylonia" at Leiden University. Her research focuses on the socio-economic history of $1^{\text {st }}$ millennium BCE Mesopotamia and is based on the cuneiform archival documentation from this time period. Among her primary interests are ancient state structures and the institutions of palace and temple in ancient Assyria as well as Babylonia.

Éva Jakab is Professor of Roman Law and head of the Doctoral School of the Károli University Budapest, teaching also at the University of Szeged. She is corresponding member of the Austrian Academy of Sciences; member of the international Jury "Consorzio Interuniversitario Gérard Boulvert" (Naples). She completed her studies in Legal History at the LMU Munich as a DAAD and Humboldt fellow; recently she spent two terms in Oxford as Visiting Fellow at All Souls College. Since 2008 she is member of the Steering Committee of the international research group "Legal Documents in Ancient Societies (LDAS)", engaged with comparative studies. Her main research field is Roman law, with a strong comparative aspect regarding the law of the provinces, focused on everyday practice as mirrored in documentary texts. She published several books and articles in German, English, Italian, French, and of course in Hungarian.

Andrea Jördens is Professor of Papyrology at Ruprecht-Karls-Universität Heidelberg, director of the Heidelberg papyrus collection and chief editor of Sammelbuch und Berichtigungsliste der griechischen Papyrusurkunden. Apart from editions of Greek documentary papyri, she has published numerous studies on the economic and social history of the "Greek Millennium" in Egypt. In addition to her focus on administrative and legal history, her recent work has concentrated on topics in culture and religious history.

Miklós Könczöl is associate professor at Pázmány Péter Catholic University, and research fellow at the Institute for Legal Studies, Centre for Social Sciences, Budapest. His research focuses on the history of legal rhetoric, theory of argumentation, and political philosophy.

Thomas Kruse gained his PhD in 2002 at Heidelberg. He has held several positions at the Institute for Papyrology of the University of Heidelberg, and was appointed Senior Lecturer in Ancient History in 2004. Since 2009 he works as a Senior Researcher at the Austrian Academy of Sciences, where he currently heads the working group for Ancient Legal History and Papyrology at the Institute for the Study of Ancient Culture. The focus of his research is on the history and the administrative institutions of Ptolemaic and Roman Egypt. 
David Lewis is Lecturer in Greek History and Culture at the University of Edinburgh, Scotland. He works on the history of labour in ancient Greece, with a particular focus on slavery. He is co-editor (with E. M. Harris \& M. Woolmer) of The Ancient Greek Economy: Markets, Households and City-States (Cambridge University Press, 2016), co-editor (with E. Stewart \& E. M. Harris) of Professionals and Skilled Labour in the Greco-Roman World (Cambridge University Press, 2020), and author of Greek Slave Systems in their Eastern Mediterranean Context, c. 800-146 BC (Oxford University Press, 2018).

Sandra Lippert is Directrice de recherche at the French National Center for Scientific Research (CNRS) and a member of the research team "Archéologie, Philologie, Histoire d'Orient et d'occident" (UMR 8546 - CNRS, EPHE, ENS, PSL) at Paris. Her work focuses on Demotic studies, ancient Egyptian law, and the economy of Egyptian temples in the Graeco-Roman period. Since 2000, she collaborates with Karl-Theodor Zauzich and Maren Schentuleit on the edition of Demotic texts of the Roman period from Soknopaiou Nesos in the Fayum.

Julia Lougovaya is since 2010 a research and teaching fellow in Ancient History and Papyrology at the Ruprecht-Karls-Universität Heidelberg. She works mainly in the area of Greek epigraphy and papyrology. Her current research is concerned with material aspects of writing practices in the ancient world, ancient education, and institutions in archaic Greek poleis.

Manuel Molina is Research Professor at the Spanish National Research Council (CSIC, Madrid) since 2008. He has published numerous editions of Sumerian legal and administrative documents, currently kept in the British Museum and in other collections. $\mathrm{He}$ has also written on administrative, social and economic topics in III $^{\mathrm{rd}}$ millennium Mesopotamian history. He is the editor of the online resource Database of Neo-Sumerian Texts (BDTNS, http://bdtns.filol.csic.es), which makes available to scholars a corpus of nearly 100,000 Sumerian and Akkadian administrative cuneiform tablets dated to the NeoSumerian period (c. 2110-2003 BC).

Nicola Reggiani is research fellow in Papyrology at the University of Parma, where he focuses mostly on Greek medical papyri and digital papyrology. His post-doc within the project Synopsis at the Heidelberg Istitute of Papyrology dealt with the administrative and writing mechanics of official reports in Graeco-Roman Egypt.

Patrick Sänger is Professor of Ancient History at the university of Münster. His main interests are the administrative, legal and social history of the Eastern Mediterranean, especially of Egypt from Hellenistic till the Late Antique period. He also devoted himself to the editing of documentary papyri and of Ephesian inscriptions. His most recent book is on the Ptolemaic form of organization "politeuma" (2019). 
Ornella Salati received her D.Phil. in Ancient History from Scuola Normale Superiore in Pisa in 2015. She is currently a Post-Doc Researcher at the University of Naples 'Federico II' as a member of the ERC-project PLATINUM. Her research interests include Roman military history, especially in the Eastern empire, and papyrology.

Maren Schentuleit is Associate Professor for Egyptology and Coptic Studies at Oxford University and Lady Wallis Budge Fellow of University College. She has been researching Greek and Demotic sources from Soknopaiou Nesos for almost two decades and collaborates with Karl-Theodor Zauzich, Sandra Lippert, Martin Stadler and Marie-Pierre Chaufray on the edition of Demotic texts from this site.

Katelijn Vandorpe is Professor of Papyrology and Ancient History at the KU Leuven University, Belgium, and a member of the Royal Flemish Academy of Belgium. Her main research field is Greco-Roman Egypt, and her publications include archival research, studies on seals, onomastics, institutions, socioeconomic aspects of this multicultural society and text editions (e.g. with T. Christensen and D.J. Thompson: P. Haun. IV 70).

Nick Vaneerdewegh graduated in Ancient History and Policy Economics, and is currently a PhD student who is part of a project on tax burden in Ptolemaic Egypt at the KU Leuven, directed by K. Vandorpe.

Uri Yiftach is Professor at Tel-Aviv University, and he is an Ancient Historian, Classical Philologist and Papyrologist. He has extensively studied scribal traditions, legal institutions, and administrative practices in Ptolemaic and Roman Egypt. His current interest is primarily linguistic. 


\title{
Headers for lists and accounts in ancient documents and in modern editions
}

\author{
Willy Clarysse, Leuven
}

Accounts and lists form a large group among the papyri and ostraca. A quick search in TM resulted in 5607 Greek accounts and 3820 lists. There are, however, numerous overlaps. The German word "Verzeichnis", for instance, used in the HGV and in TM, can indicate both a list (e.g. Verzeichnis von Einwohnern, von Inhabern von Grundstücken) or an account (Abrechnung; Verzeichnis; Verzeichnis von Ausgaben; Verzeichnis von Personen mit nachfolgenden Summen).

\section{1) The headers of modern editions}

The papyrological terminology for the types of texts we are discussing in this conference is created by the editors, who usually group their texts according to types (contracts, letters, receipts, with "accounts and lists" often at the end of the documentary texts) and/or provide each text with a header. These headers are chosen by individual editors and there is no uniform terminology in TM nor in HGV because the online databases simply copy the terms used by the editors. A typical example of editorial practice is provided by the table of contents of P. Bingen (accounts and lists are underlined):

27. Ptolemaic tax account

31. Elenco di indigeni con connotati personali

36. Ptolemaic apomoira account

38. Abrechnung

42. List of names

43. Conto

71. Aufstellung über Personen und Land

72. Aufstellung über Personen und Beträge in Weizen

76. Conto

77. Registre de navires marchands

79. Ausgaben für Faustina

99-101. Liste de noms

109. Registro di ekphoria

116. Greek account on a clay tablet

117. List of household items

119. Account of expenditures in wheat

120. Account of expenditures in money

127. Abrechnung über Kornverteilung an die Bettler

135. List of payments 
136. Abrechnung über Getreidelieferungen

137. Verzeichnis von Ausgaben

139. Verzeichnis über Getreideablieferung

140. Verzeichnis von Landbesitz

142-144. Namensliste

145. Zahlungsliste

146. Verzeichnis von Abgaben

Table 1. P. Bingen headers

The lack of interest in terminology is also visible in the recent Handbook of Papyrology, where B. Palme wrote a chapter on "the range of documentary texts", with a short paragraph called "accounts" (Palme 2009, 370-371). Here he speaks about "an extensive group of private documents (where are the administrative accounts in this typology?), described broadly as economic texts, includes accounts of all kinds, receipts, orders for payment, proofs of banking, lists of incoming and outgoing money or goods, transport lists and much more." Different types of documents (such as receipts and orders for payment) are here lumped together with the accounts and lists. One also wonders what are "lists of payments", "Verzeichnis von Ausgaben/Abgaben" (items 137 and 146 in the list above), "lists of incoming and outgoing money", "Zahlungsliste" (P. Vindob. Salomons 17-18) and "Abrechnungsliste" (SB VIII 9697) if not accounts.

My study starts from a database of all lists, accounts, registers and inventories, which do have a header in the Greek text [http://www.trismegistos.org/tmcorpusdata/7/]. I excluded from the present study headers consisting of a date, a place ( $S B \times 10220)$, the name of a

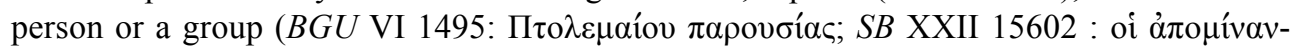

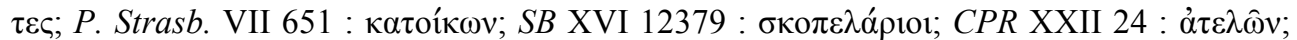

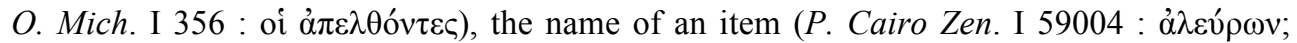

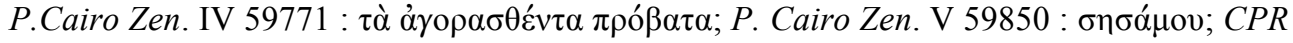

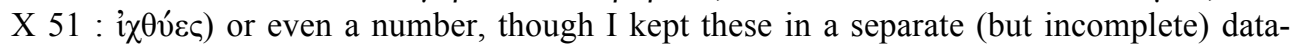
base. In many cases the word for "account" is omitted, as e.g. in P. Cairo Zen. IV 59542,

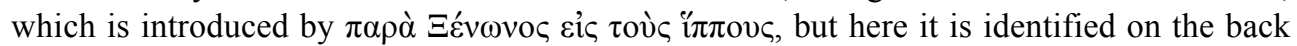

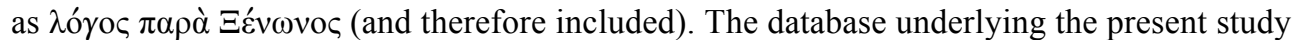
is limited to list-like documents which identify in their header (or, rarely, on the back) the

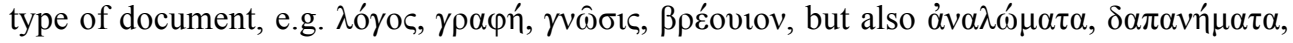
$\lambda \eta^{\prime} \mu \mu \alpha \tau \alpha$, or $(\dot{\alpha} \pi) \dot{\varepsilon}_{\chi} \omega$ and $\alpha \dot{\alpha} \varepsilon \delta \omega \kappa \alpha$. This resulted in some 1200 texts, i.e. nearly $13 \%$ of the accounts and lists (9400 items) bear a header indicating the type of text. Given that there are many overlaps between the two categories and that maybe a quarter of our texts have lost their first lines, this is number is higher than I expected.

Starting from this material, I have tried to bring some order into the different types of documents. The two main categories are accounts and lists. This distinction is for instance the basis of two chapters in $O$. Bodl. When I made this distinction explicit, I had to decide for every text and every text type to which category it belonged. I started of course from the typology of the editors, but it was soon clear that their decision to call a text "account" or "list" was sometimes subjective. This is illustrated by a few examples in table 2. 


\begin{tabular}{|l|l|l|l|}
\hline ed. princ. & type & other edition & type \\
\hline $\begin{array}{l}\text { P. Cairo Zen. I } \\
59014\end{array}$ & porterage account & $\begin{array}{l}\text { SB XXVI 16505 } \\
\text { and HGV }\end{array}$ & Liste von Transportgütern \\
\hline SB XVI 12822 & Abrechnung & P. Gen. IV 204 & $\begin{array}{l}\text { liste de sommes dues pour } \\
\text { l'impôt }\end{array}$ \\
\hline P. Strasb. V 320 & liste de contribuables & P. Sakaon 8 & account of meat \\
\hline P. Tebt. I 96 & list of arrears & $\begin{array}{l}\text { Berkeley } \\
\text { homepage }\end{array}$ & account of arrears \\
\hline $\begin{array}{l}\text { P. Tebt. IV } \\
1126\end{array}$ & list & P. Tebt. IV 1128 & account \\
\hline
\end{tabular}

Table 2. Different headers in different editions of the same or similar texts

$P$. Bingen 150 is called a "Coptic account", but the header TErNWCıC NECOY is translated as "the list of wheat". The text looks indeed like a shipping list, but as there is a total of artabae at the end, I have classified it as an account.

By trial and error I gradually defined the difference between lists and accounts : for an account one needs at least figures. But not every enumeration with figures is automatically an account. An account also needs a common denominator, which allows the user to count the number of items. Thus one can have an account of oxen, of pigs, of fishes delivered, of requisitioned donkeys, of workmen on a building plot, of pastries, but not an account of cloths, ceramics and metal objects mixed together. There is, however, a way to count different objects as if they are not a single category : by giving them a common denominator, usually by adding a price in money or in grain. This allows to count different objects together, though the price alone is not enough to speak of an account : there must be the intention to count the total value of the things enumerated. Therefore dowry lists (with value added) or registers of land (no totalisation of the areas of the plots) are not considered by me as accounts.

Often a text can therefore be recognised as an account because it has a total at the end (or at

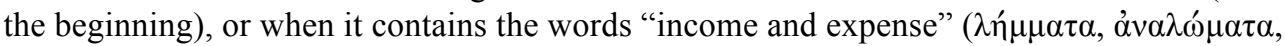
$\left.\delta \alpha \pi \alpha v \eta^{\prime} \mu \alpha \tau \alpha\right)$. In most cases it is not too difficult to make the distinction between simple lists and accounts. The following table shows 30 of about 100 instances where I have corrected the headers of the editors. Some problems remain, however, especially with fragmentary texts.

\begin{tabular}{|c|c|c|c|}
\hline typology of the editor & reference & my typology & Greek header \\
\hline $\begin{array}{l}\text { Liste von Einnahmen } \\
\text { und Ausgaben }\end{array}$ & $C P R$ VIII 22 & account, money & 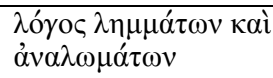 \\
\hline Liste von Ausgaben & P. Amst. 76 & account, money & हैк $\theta \varepsilon \sigma ı \varsigma$ \\
\hline Ausgabenliste & $S B \times 10742$ & account, fragmentary & $\lambda \operatorname{\gamma o}_{0} \delta \alpha \pi \alpha \nu \omega \hat{\omega} v$ \\
\hline Ausgabenliste & $S B$ XVI 12291 & account, money & $\delta$ óбıৎ \\
\hline Ausgabenliste & P. Strasb. II 119 & account, money & 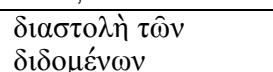 \\
\hline Liste von Zahlungen & P. Amst. 85 & $\begin{array}{l}\text { account, money, end } \\
\text { total }\end{array}$ & 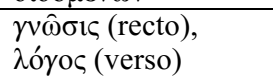 \\
\hline
\end{tabular}




\begin{tabular}{|c|c|c|c|}
\hline Liste von Zahlungen & $S B \times X 14216$ & $\begin{array}{l}\text { account, money, end } \\
\text { total }\end{array}$ & $\lambda \operatorname{ló}_{\mathrm{o}} \varsigma \tau \hat{\omega} \mathrm{v} \delta \mathrm{o} \theta \dot{\varepsilon} v \tau \omega \mathrm{v}$ \\
\hline Liste von Zahlungen & $S B \times X X 14537$ & account, money & $\lambda o ́ \gamma о \varsigma$ \\
\hline Liste von Zahlungen & $S B \times 10551$ & account, money & $\lambda{ }^{\prime} \gamma о \varsigma \delta \rho \alpha \chi \mu \hat{\omega} \nu$ \\
\hline Namenliste mit Abgaben & P. Köln XIII 533 & $\begin{array}{l}\text { account, grain, with } \\
\text { end total }\end{array}$ & 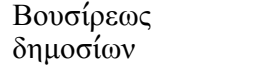 \\
\hline $\begin{array}{l}\text { Liste mit Namen und } \\
\text { Zahlungen }\end{array}$ & $S B \times X X 14077$ & $\begin{array}{l}\text { account, money, with } \\
\text { initial and end total }\end{array}$ & no header \\
\hline List of expenses & P. L. Bat. XXV 79 & account, grain & 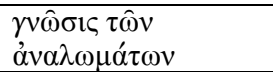 \\
\hline List of expenses & P. Kellis I 53 and 54 & account, money & $\lambda o^{\prime} \gamma \circ \alpha_{\alpha}^{\prime} v \alpha \lambda \omega \mu \alpha \alpha^{\prime} \tau \omega \nu$ \\
\hline $\begin{array}{l}\text { Liste von verschuldetem } \\
\text { Wein }\end{array}$ & P. Amst. 78 & $\begin{array}{l}\text { account, wine (in } \\
\text { dipla) }\end{array}$ & 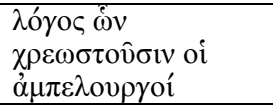 \\
\hline Steuerliste & P. Münch. III 139 & $\begin{array}{l}\text { account, money, end } \\
\text { total }\end{array}$ & 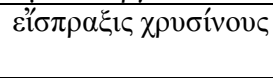 \\
\hline $\begin{array}{l}\text { Liste von } \\
\text { Steuerschulden }\end{array}$ & P. Amst. 84 & account, money & header lost \\
\hline $\begin{array}{l}\text { Liste de sommes dues } \\
\text { pour l'impôt }\end{array}$ & P. Gen. IV 204 & account, money & 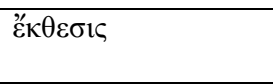 \\
\hline List of payments in kind & P. Mich. VI 376 & account, grain & 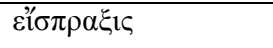 \\
\hline $\begin{array}{l}\text { Auflistung von } \\
\text { Weizenmengen }\end{array}$ & $S B \times X 14700$ & account, grain & $\begin{array}{l}\gamma v \hat{\omega} \sigma 1 \varsigma \text { бítov } \\
\dot{\alpha} \rho \tau \alpha \beta \hat{\omega} v\end{array}$ \\
\hline List of festal payments & P. Oxy. LXVII 4617 & account, money & 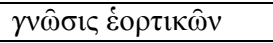 \\
\hline Liste von Festbeiträgen & $S B$ XIV 12130 & $\begin{array}{l}\text { account, wine, with } \\
\text { end total }\end{array}$ & $\lambda \operatorname{ló}_{\mathrm{\gamma}}$ \\
\hline $\begin{array}{l}\text { Auflistung von } \\
\text { Zahlungen }\end{array}$ & $S B$ XVIII 13145 & account, money & 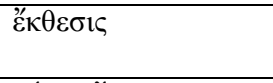 \\
\hline Auflistung von Kosten & $S B$ XXII 15332 & account, money & $\lambda o ́ \gamma о c$ है $\rho \gamma \omega v$ \\
\hline Einnahmeliste & $B G U$ XVII 2724a & $\begin{array}{l}\text { account, grain, with } \\
\text { end total }\end{array}$ & 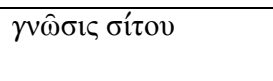 \\
\hline Zahlungsliste & Eirene III 13 & account & 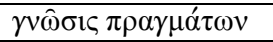 \\
\hline Aufstellung & P. Louvre I 48 & account & 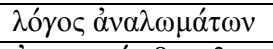 \\
\hline account of oxen & $\begin{array}{l}\text { P. Mil. Vogl. III 148- } \\
149\end{array}$ & list of oxen & 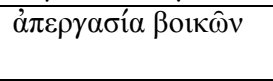 \\
\hline $\begin{array}{l}\text { account of requisitioned } \\
\text { animals }\end{array}$ & O. Kellis 103 & $\begin{array}{l}\text { list of requisitoned } \\
\text { donkeys }\end{array}$ & 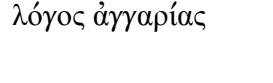 \\
\hline account of arrears of oil & O. Kellis 98 & $\begin{array}{l}\text { list of arrears (no } \\
\text { figures) }\end{array}$ & 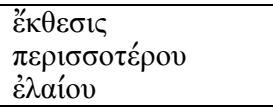 \\
\hline compte de patisseries & P. Strasb. V 339 & list (no value) & $\lambda$ ó \\
\hline private account & P. Wash. I 58 & $\begin{array}{l}\text { inventory, with value } \\
\text { of the items }\end{array}$ & 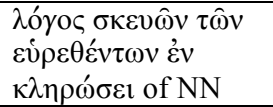 \\
\hline
\end{tabular}

Table 3. Headers in the editio princeps different from my typology 
The database now lists 825 accounts and 358 lists. Fourty-seven texts of similar type remained unclassified and there are some overlaps. Part of the unclassified texts were too fragmentary to be determined, others are registers of landed property. Though lists of owners of land [there are 28 of them] often contain figures of the area in possession of a person or even of the produce of the land, they are nowhere considered accounts by the editors (see e.g. the P. Bingen listing in table 1 above).

Among the lists a special mention is due to inventories [33 in the database]. These offer a complete enumeration of all possessions of an individual or an institution at a certain point in time (dowry lists at marriage, lists of inherited property, lists of books in a library). Sometimes the value of the items listed is added, but they clearly are not accounts.

Among the 837 accounts 478 are accounts of money, 185 accounts of grain and 197 accounts where neither money nor grain were involved. In 70 cases the account registers both income and expense, in 168 they deal with income alone and in 208 with expenses alone. Since income for one person, group or institution usually means expense for other parties, it is not always clear what category is meant. Datives of personal names or groups are counted as expenses; $\pi \alpha \rho \dot{\alpha} \mathrm{NN}$ is listed as income; but what to do when the name is in the nominative? In a document of the administration taxes are income, in a private document they are expenses; therefore the type of document is not always clear to the modern reader.

Both lists and accounts can be private or official (emanating from or directed to a governmental office). There are many more private lists, but only a minority has a header.

\begin{tabular}{|l|l|l|l|}
\hline & private & official & estate \\
\hline account & 298 & 357 & 70 \\
\hline list & 87 & 198 & 8 \\
\hline
\end{tabular}

Table 4. Accounts and lists. Private, official and estate documents.

\section{2) Headers in the Greek papyri}

The most common header by far is the word $\lambda$ óyoc, which is found in 552 out of 1156 instances, from the Ptolemaic up to the Arab period. Even in Coptic this is a common header $^{1}$. The word is used for both lists and accounts, which means that the translation given by the editors ought to be checked : English or French have no word for the two, like German Verzeichnis.

1 P. Köln ägypt. II 62, Coptic text written on paper is an account of wine (גoroc NHPn) dated to the 10th cent. AD. 


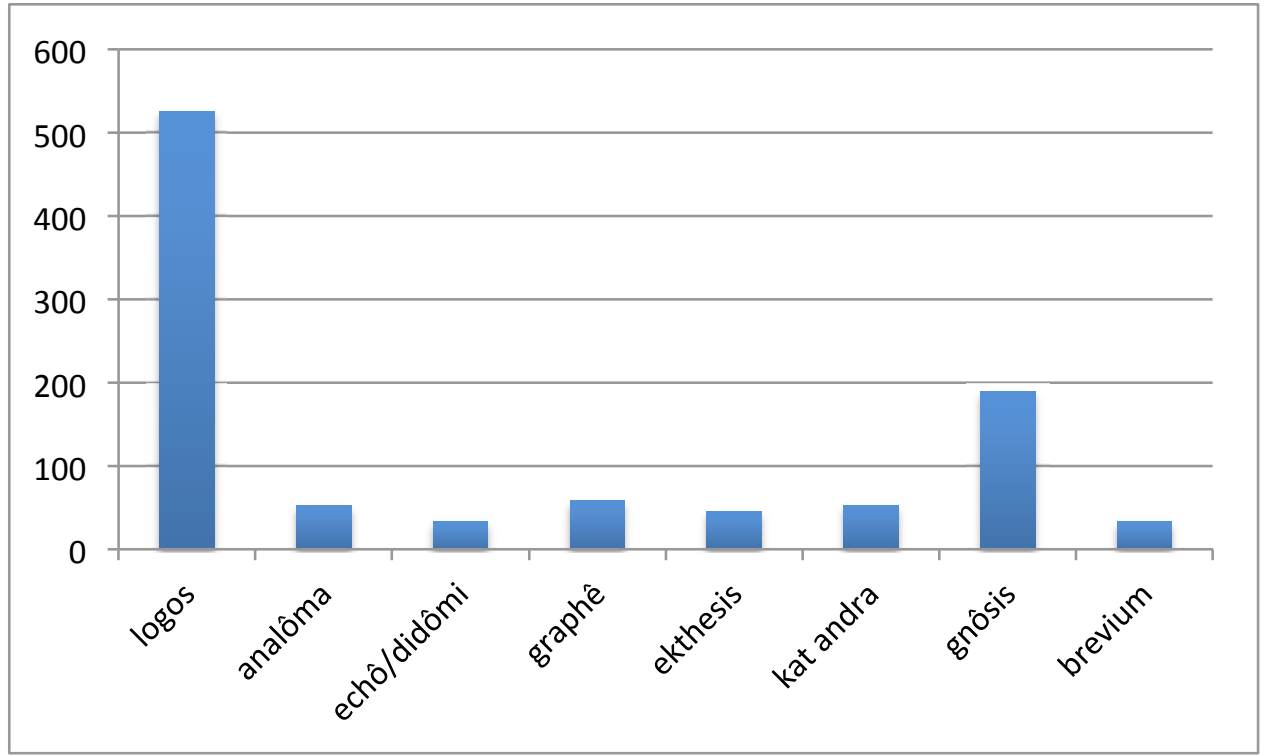

graph 1 : The main Greek words used as headers for lists and accounts

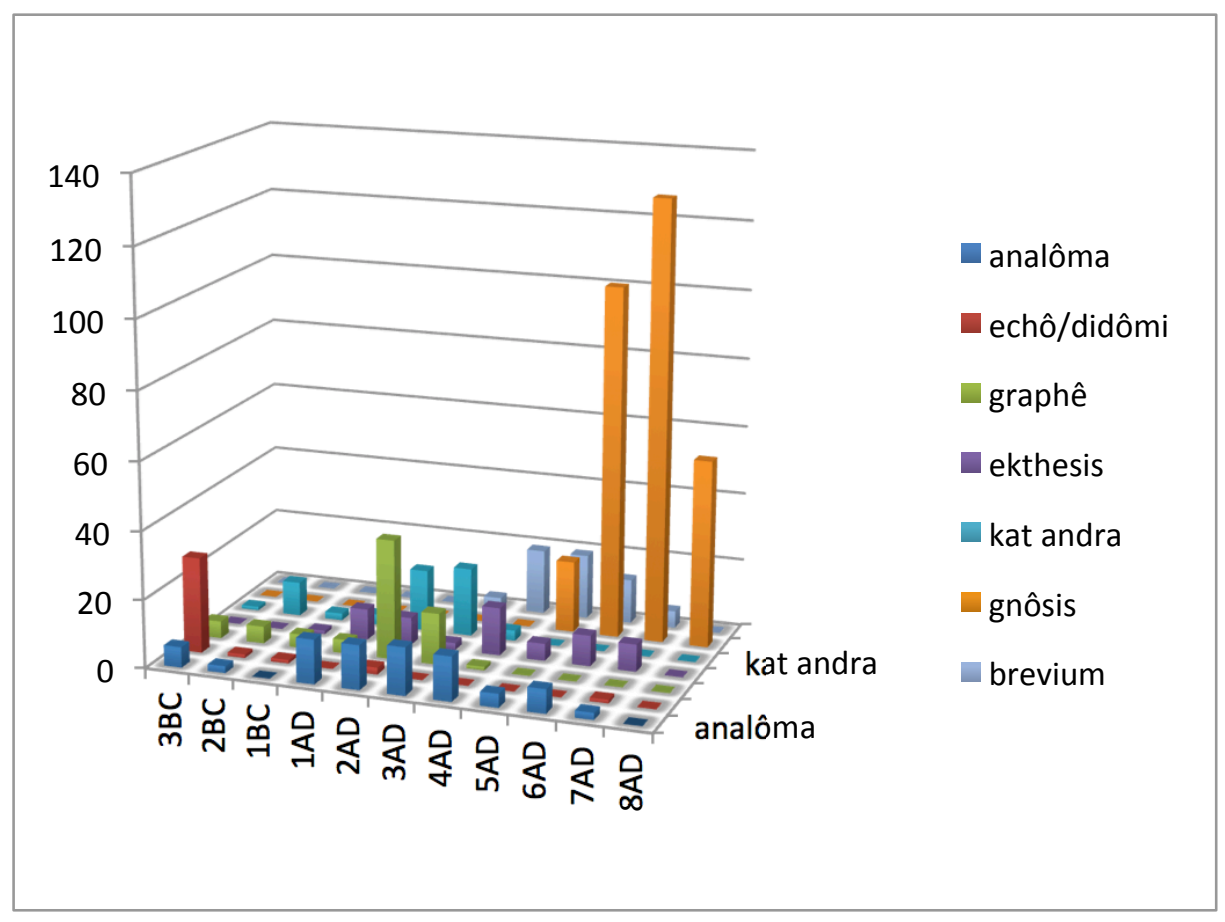

graph 2 : The main Greek words used as headers in lists and accounts (omitting $\lambda$ ó $\gamma$ oc) 
The words $\alpha \dot{\alpha} \alpha \dot{\lambda} \omega \mu \alpha$ (rarely $\delta \alpha \pi \alpha ́ v \eta$ ) and $\lambda \hat{\eta} \mu \mu \alpha$ are often put in the genitive at the beginning of an account. There are 52 instances of $\alpha v \alpha \dot{\lambda} \omega \omega \mu \alpha$, of which $32 \lambda$ ó $\gamma \circ \varsigma \dot{\alpha} v \alpha \lambda \omega \mu \alpha-$

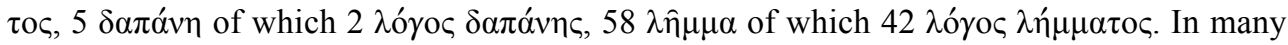

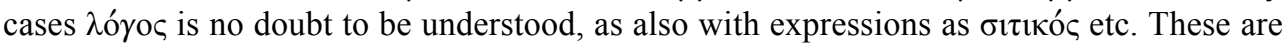
certainly accounts, with indication of income and expense.

Logos is also to be understood with $\kappa \alpha \tau^{\prime}{ }^{\prime \prime} v \delta \rho \alpha$ [there are $56 \kappa \alpha \tau^{\prime}{ }^{\prime} \alpha \delta \rho \alpha$ items in the database], though this expression is never explicitly combined with $\lambda$ ó $\gamma \circ \varsigma$ (once with $\sigma \omega \mu \alpha \tau \imath \sigma-$ $\left.\mu \varsigma_{\varsigma}\right)^{2}$. The expression $\kappa \alpha \tau^{\prime} \alpha^{\prime} v \delta \rho \alpha$ clearly belongs to the administrative language in the Ptolemaic and Roman period. The earliest examples are found in the second cent. BC, the term occurs repeatedly in the archive of Menches (late 2 nd cent. BC), also as a header for land surveys. It disappears after the third century $\mathrm{AD}$, with only three fourth cent. examples, one of which is uncertain ${ }^{3}$.

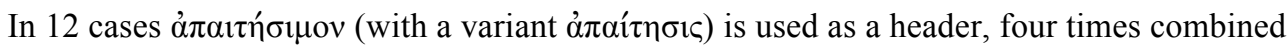
with $\kappa \alpha \tau^{\prime}$ ' $\alpha \delta \delta \rho \alpha^{4}$. Though $L S J$ translates the word as "list of land subject to dues" it can indicate all kinds of stately dues. In all cases amounts in money or grain are mentioned and we have listed the apaitesima as accounts rather than simple lists.

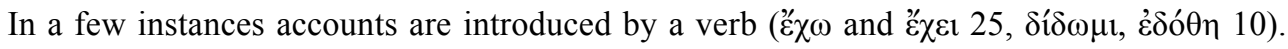

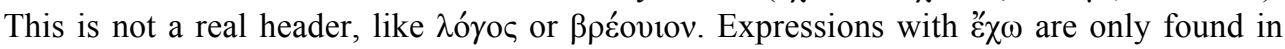
Ptolemaic texts (mainly in the Zenon and Dryton archives), those with $\delta$ í $\delta \omega \mu$ c continue sporadically into the Arab period (e.g. P. Oxy. XVI 2045).

"̌ $\kappa \theta \varepsilon \sigma \iota \varsigma$

With a single exception, which may belong to the very end of the first cent. BC (P. Tebt. II 573 descr.) all 45 examples of this word date from the Roman to the Arab period. Editors often translate it as "arrears", probably on the basis of Preisigke's Fachwörterbuch, p. 7, but as a header it simply means "list" ". Forty out of 45 instances are clearly accounts, but there are also some lists of cloths without valuation in money, which are therefore lists. The term comes from the administrative language (31 out of 45 texts are official and none is clearly private).

Графи́ occurs 63 times as a header. In the Ptolemaic period it is used for any kind of list or inventory (e.g. P. Dryton 38), in the Roman period it is the usual word for administrative lists of persons, especially lists of liturgists and lists/inventories of priests and possessions

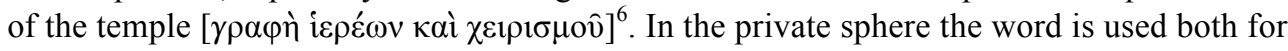

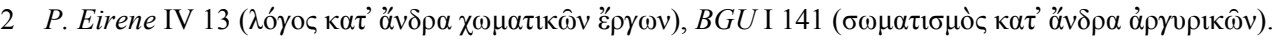

3 P. Sakaon 8 (AD 309); 4 (AD 336). SB XX 14468 is dated AD IV by Sijpesteijn, but the names and the money figures (drachmas and obols) rather point to a date before AD 275.

$4 \quad B G U$ II 659; $B G U$ XIII 2282; SB XIV 11505; Stud. Pal. XXII 88.

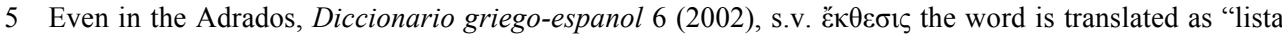
de atrasos de pago pendientes o sumas adeudadas al fisco". In LSJ the meaning "list" is mentioned sub VIII, with one single example from the papyri.

6 Cf. F. Burkhalter, Le mobilier des sanctuaires d'Egypte, ZPE 59 (1985), p. 123-134. 
lists and for accounts [SB VI 9245; P. Lond. VII 1994; PSI IV 427, with a total on the back], but in the public sphere it became a terminus technicus for listing groups of persons with a special status ${ }^{7}$. 'Av $\alpha \gamma \rho \alpha \varphi$ n is used 12 times from the Ptolemac to the Arab period. In at least five cases it clearly points to an inventory ${ }^{8}$, but it can also be a list of fishermen (P. Oxy. LXIV 4440) or an account of expenses (P. Lond. IV 1447).

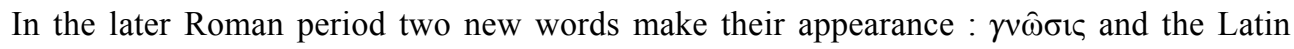
loanword $\beta \rho \varepsilon$ śoviov. Only the former also makes it into Coptic.

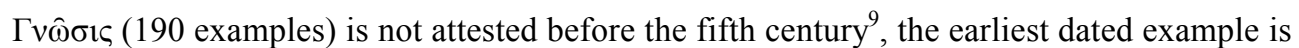
even sixth century (AD 514; P. Cairo Masp. I 67014). Since lists of the Byzantine period are normally undated and palaeographical datings are often vague (two centuries timespan or even more) the graph above probably mispresents the real situation and gnôsis becomes common only from the sixth century onwards (texts dated AD 400 - 599 are divided over the fifth and sixth centuries in the graph, but no doubt most of them belong to the sixth century). The word remains popular up to the eight century, and is also used in Coptic, both for accounts (e.g. SB I 5303) and lists (e.g. P. Bingen 150; CPR XII 6), though editors tend to prefer the translation "list" even in cases where gnôsis is certainly an account ${ }^{10}$.

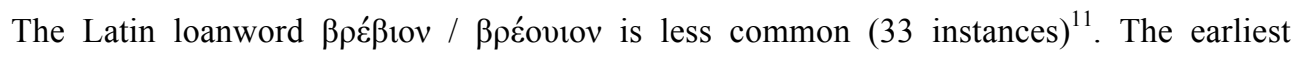
examples date from the late third or early fourth century, the time of the tetrarchy, when many Latin loanwords entered the administrative language. Again the word indicates both lists and accounts; in the archive of Abinnaeus it is used as an official term, but some of the fourth century examples are private (estates). Most occurrences date to the fourth century and in the fifth century the word seems to fall out of use (only two uncertain examples of the 6th century, no examples in Coptic). With three exceptions (an inscription from Chalkis = Sylloge II 905.17, the Vita Chrysostomi of Palladius 3.90 and two passages in the codex of Iustinianus) all examples given in Adrados' lexicon are from the papyri.

7 Therefore in the report of a village scribe PSI Communicazione 612.3 the general [ $\lambda$ ó $\gamma \circ \varsigma] \mu \eta \chi \alpha \nu \omega \hat{v}$ is a

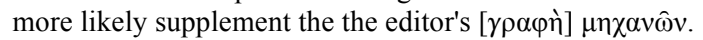

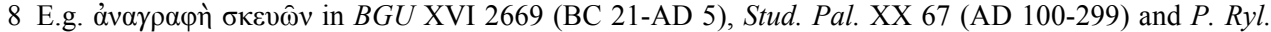

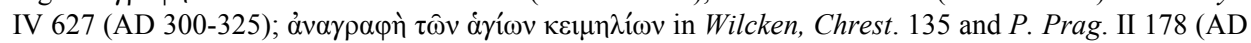
400-599). For inventories, see W. Clarysse, Inventories in Coptic churches and monasteries, in : K. Vandorpe - W.Clarysse (edd.), Archives and inventories in the Eastern Mediterranean, Contactforum Koninklijke Vlaamse Academie, Brussels 2006, pp. 85-93.

9 Three instances are dated AD 300 - 699 in TM: SB I 4759 B, 4888, 5303 (all three dated by Wessely, to the "byzantine period" and certainly 5 th century at the earliest).

10 The meaning "list" seems clear in an important inscription from Perge, dated about AD 500, quoting a speech by the emperor Anastasius. The text is now published in Gephyra 14 (2017), p. 133-212, see

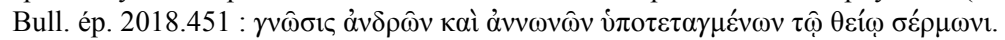

11 For this word, see most recently A. Maravela-Solbakk, ZPE 149 (2004), p. 184, who refers to Lex. Lat. Lehnwörter II, 207-210. 


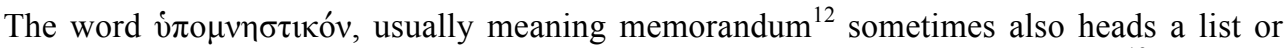
account, though perhaps the term only gets this meaning from the context $t^{13}$. See for instance P. Jena II 37 (ن் 599); P. Fouad 74 (list of objects to buy in Alexandreia, introduced by a short memorandum, followed by the usual ov̈ $\tau \omega$ ), P. Iand. IV 67 (called a ratiuncula by the editor; the

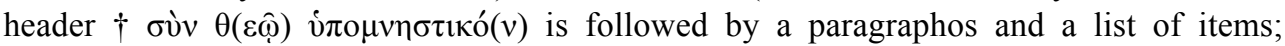

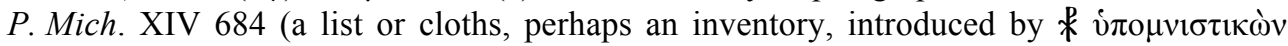

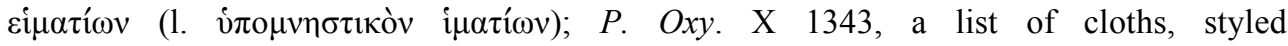
$[\dot{v}] \pi \circ \mu \backslash v / \eta \sigma \tau \iota \kappa($ óv) on the verso.

\section{The lay-out of accounts and lists}

Papyrus texts are usually written in scriptio continua and features of lay-out are the exception rather than the rule. Contracts for instance go on without interruption from beginning to end, letters and petitions are often marked by a separate last line with the final

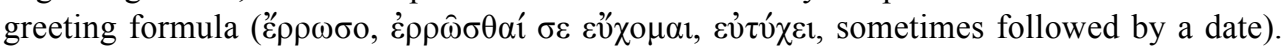
In accounts and lists the lay-out of the text is much more elaborate than in most other papyrus texts :

- a new line is usually taken for each item in the list

- figures are usually put in a separate column towards the right margin

- headers are often marked by a separate first line.

12 E.g. in P. Abinn. 42 (AD 326-375); P. Ant. II 92 and PUG I 29 (AD IV-V); SB XII 11084 and XX 15191 (AD V); P. Köln XIII 545 (AD 400-599); P. Flor. III 359 (AD 500-599); P. Oxy. XVI 2059 (AD VII).

13 P. Fouad 74 (AD IV) is a memorandum followed by a list; P. Cairo Masp. III 67319 is headed as

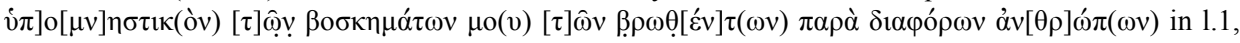
but called a $\gamma v \hat{\omega} \sigma(1 \varsigma)$ on the back. 


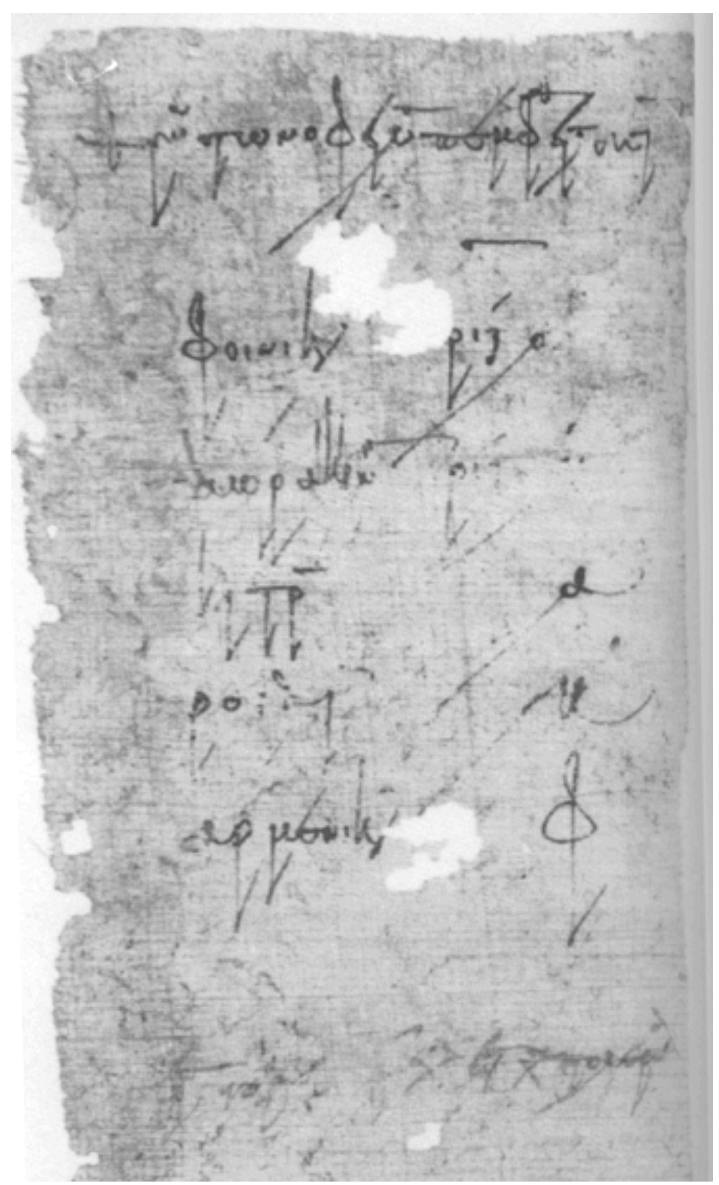

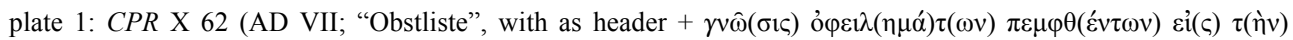

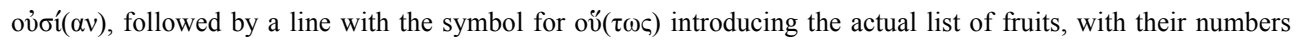
and prices. The last line, in a different hand, gives the date and the destination ("for the chorion Ptolemais") of the goods bought.

Official accounts and lists are often incorporated into memoranda or letters. Here too the lay-out clearly shows where the list itself begins : usually a new line is started, often there is an open space between the introductory formula and the list and this can be accentuated by the use of some expressions, such as है $\sigma \tau \imath \delta \varepsilon$ and ỡ $\tau \omega \varsigma$.

The use of a paragraphos under the header lines is exceptional. I found it sporadically in the Menches archive (P. Tebt. I 67, 69, 70, 84) and then again in some papyri from the Arab period (CPR XII 8, though these are rather division lines; P. Lond. IV 1413; 1418), but fourteen instances on more than a thousand papyri shows that this device remained uncommon. 
In official documents of the Roman period the list or account proper is often introduced by the expression $\varepsilon^{\prime} \sigma \tau \iota \delta \varepsilon^{\prime}$, sometimes written in scriptio continua with what precedes ("unmarked") but more often positioned at the end of a line (often marked by a space before it) or in a separate short line, dividing the prescript from the list of objects or persons. This is found in 75 texts in the database, 60 of them clearly official (texts written by village scribes or sitologoi for instance) and in 10 belonging to large estates like that of Appianus, who copied administrative habits. Because the texts are nearly all official most of them carry a date. This allows us to date the expression rather precisely : the earliest examples date from AD 116 (P. Giss. I 58, a list of liturgists) and 134 (BGU IX 1891) respectively, the latest from AD 338 (P. Lips. I 97) and 361 (P. Oxy. LXVII 4599).

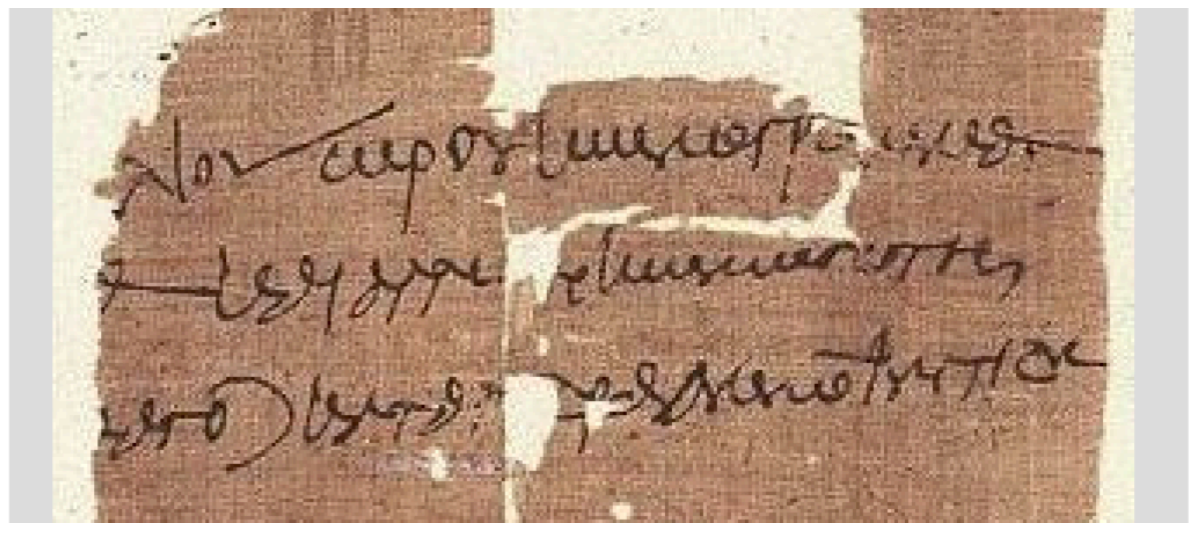

plate 2: SB XXVI 16824 : ‘̌ $\sigma \tau \imath \delta \varepsilon$ at the end of 1.3 (unmarked)

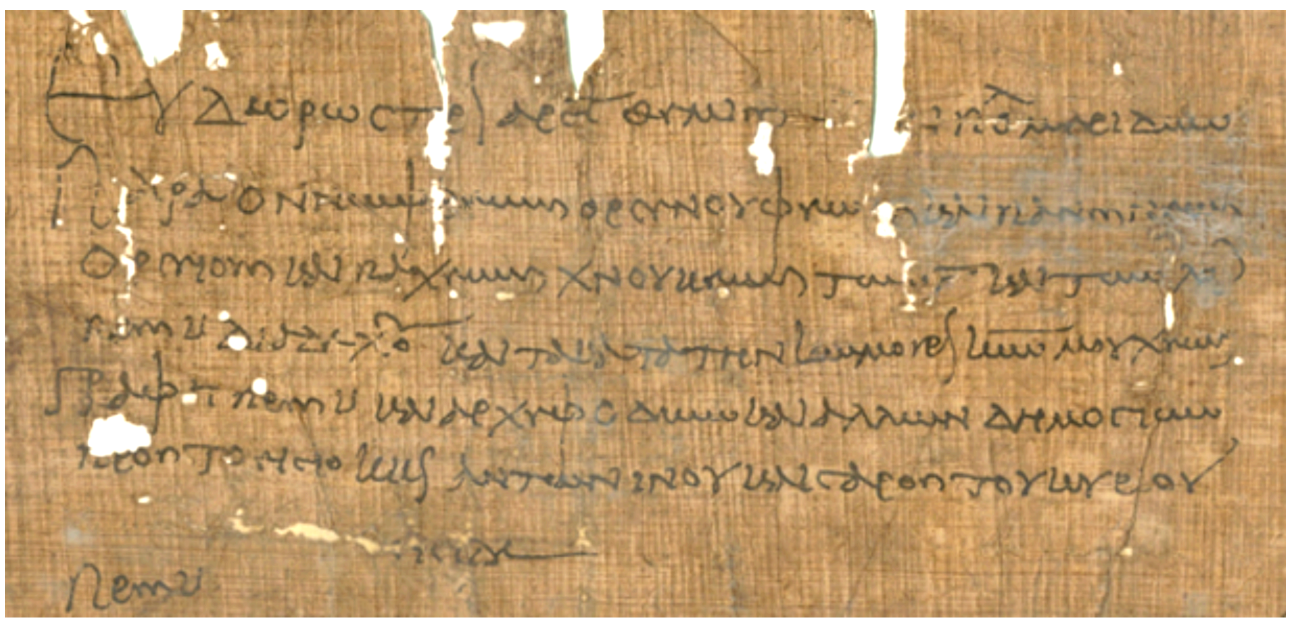

plate 3: BGU I 6 : '̌ $\sigma \tau \imath ~ \delta \varepsilon ́$ in a separate line 7

Only once, in P. Oxy. LXVII 4599 (AD 361) the $̌$ $\sigma \tau \imath ~ \delta \varepsilon ́$ formula is found side by side with a new expression, introducing the list proper by means of the word oü $\omega \varsigma$. This word is 
found from the fourth cent. $\mathrm{AD}$ up to the Arab period, both in private and official texts, often difficult to date (because of the indiction system). At first the word is written fully out at the end of the prescript or in a separate line, later on it is usually abbreviated into a horizontal line beginning with a short omikron. In a few cases older editors have even transcribed it as a paragraphos, but that is clearly not the case.

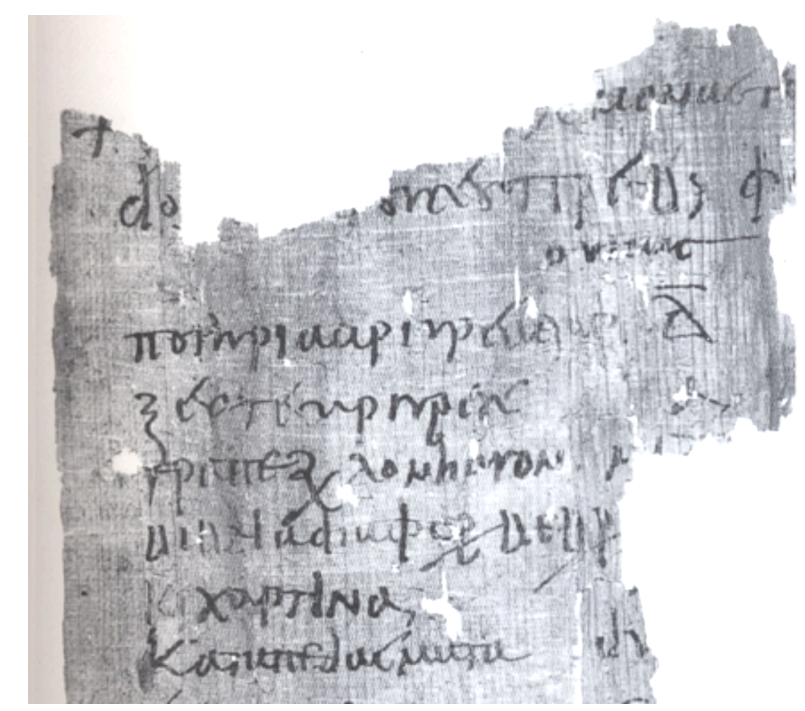

plate 4: P. Prag. II 178 (ő̋ $\omega \varsigma$ written fully out in 1.3)

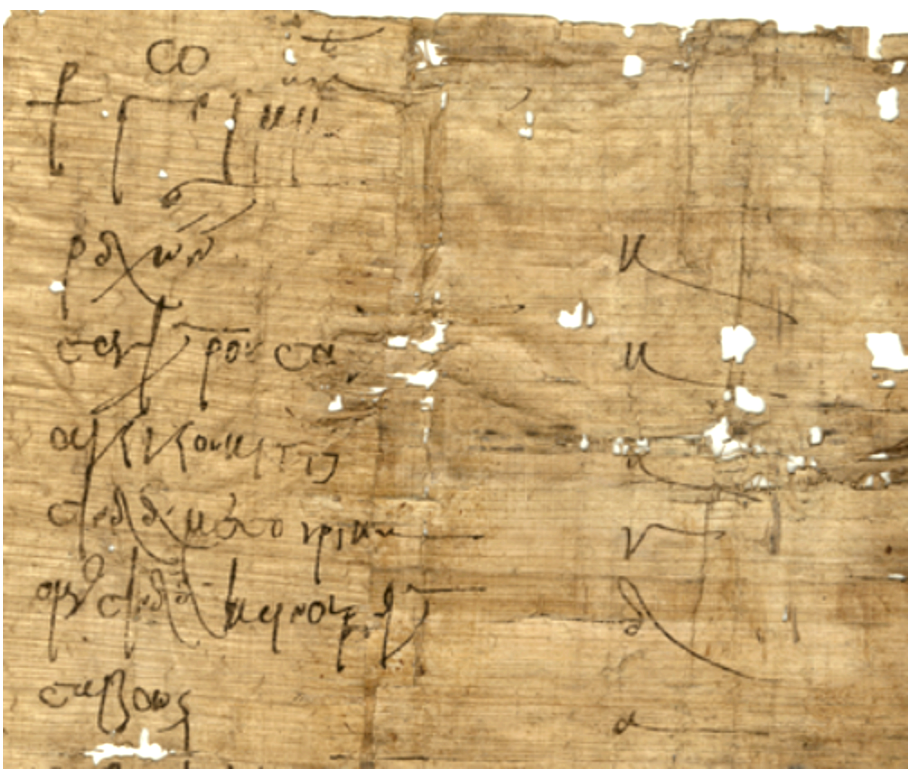

plate 5: P. Oxy. LXXVII 5126 (ő̋ $\omega \varsigma$ abbreviated in 1.2) 
In the Byzantine period the headers are often preceded by a cross (see plate 1), a chrisma or a monogrammatic cross (plates 4 and 5). The earliest certain example of a cross is $C P R$ VIII 37, which can be dated to about AD 350 because bishop Dios mentioned here in 1. 10 must be identical with the bishop in P. Landl. II 1.147 (AD 346) ${ }^{14}$. The more elaborate christian symbolic figures XMГ and $\mathrm{Q} \Theta$ are not attested before the fifth century ${ }^{15}$.

\section{The order inside accounts and lists}

The headers of accounts and lists do not usually give explicit information about the order followed in the texts, except for the $52 \kappa \alpha \tau^{\prime}$ ' $\alpha \delta \rho \alpha$ lists which list persons by name (this order is called $\kappa \alpha \tau$ ' oै $v o \mu \alpha$ in $C P R$ VIII 44). Alphabetic order remains exceptional, I found only three instances (BGU IX 1897, AD 166; P. Strasb. I 27, AD I-II; Stud. Pal. XXII 88, AD 214$)^{16}$. Other possibilites are listing by date (usually by day), by place and by item (normal with inventories). The following table shows how these different possibilities are spread

\begin{tabular}{|l|l|l|l|}
\hline & lists & accounts & total \\
\hline by person & 160 & 330 & 511 \\
\hline by date & 21 & 182 & 213 \\
\hline by place & 30 & 60 & 91 \\
\hline by item & $94(24$ inventories $)$ & 90 & 185 \\
\hline
\end{tabular}

14 See K.A. Worp, ZPE 100 (1994), p. 300.

$15 P$. Mich. VI 378, which presents a cross, ХМГ and $Q \Theta$ was dated by the editor to the early fourth century (date accepted in the $H G V$ and $T M$ ), but see $B L$ VIII, p. 213 (P.J. Sijpesteijn), P. Sorb. II, p. 46 (J. Gascou) and BASP 32 (1995), p. 52 (P. van Minnen), who all plead for a fifth century date.

16 For alphabetical order in Ptolemaic land lists as early as the late second century BC, see A. Verhoogt, Menches, komogrammateus of Kerkeosiris, Pap. Lugd.-Bat. 29, p. 215. 